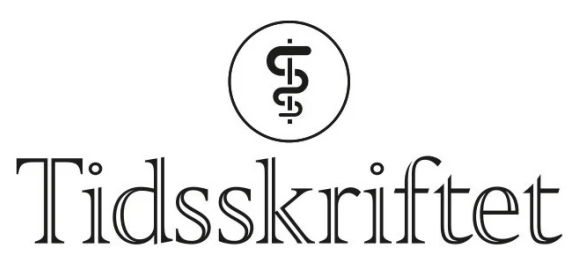

DEN NORSKE LEGEFORENING

\title{
Helse og menneskerettigheter
}

\author{
ANMELDELSER
}

JOHANNE HELENE IVERSEN

Det medisinsk-odontologiske fakultet

Universitetet i Bergen

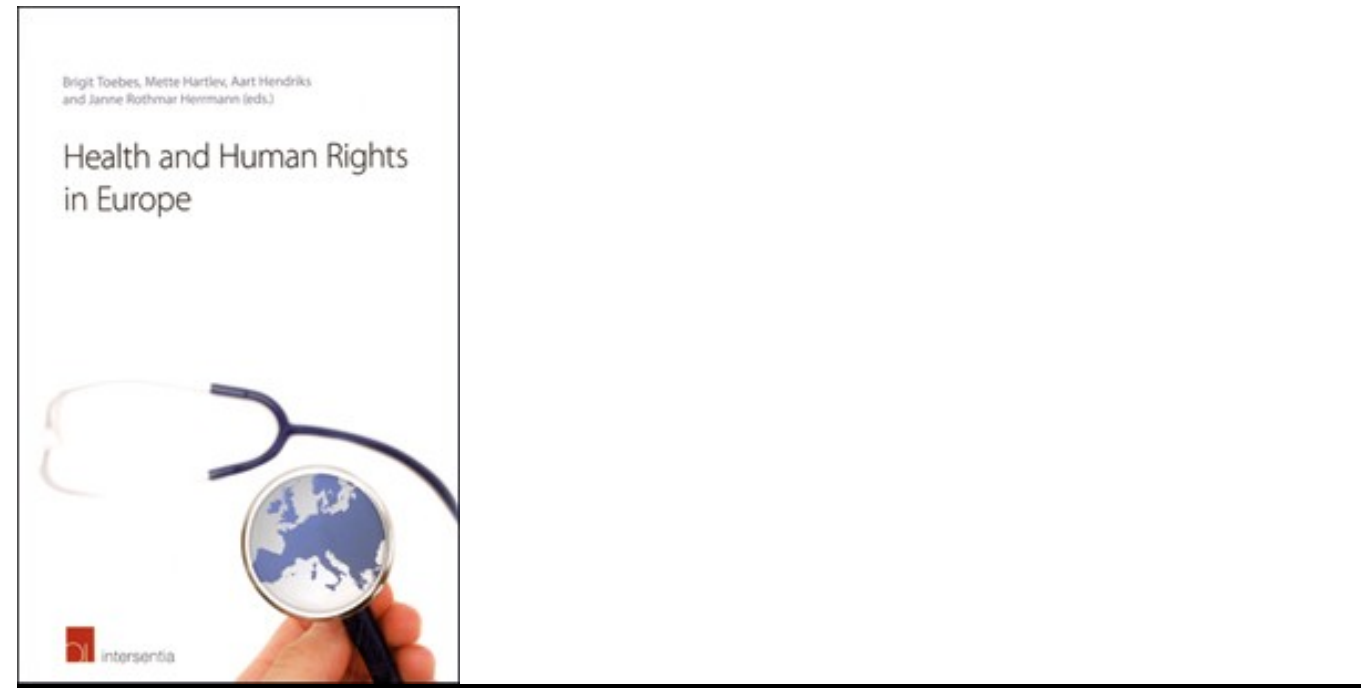

Toebes, Brigit

Hartlev, Mette

Hendriks et al, Aart

Health and human rights in Europe

310 s. Antwerpen: Intersentia, 2012. Pris EUR 69

ISBN 978-9-40000-151-O

Helse i lys av menneskerettigheter blir stadig mer brukt som begrep og argumentasjon når vi diskuterer retten til helse og helsehjelp. Det er imidlertid fremdeles liten forståelse for de ulike juridiske implikasjonene mellom helse og menneskerettigheter og hvordan dette skal brukes i tilnærmingen til helse og jus i praksis. I Health and human rights in Europe ser forfatterne nærmere på hvordan denne grenen av jus har utviklet seg fra den annen verdenskrig frem til i dag, og de diskuterer grensesnittet mellom juridisk praksis og implikasjoner av menneskerettigheter for helse. 
Å benytte en helse- og menneskerettighetstilnærming betyr å bruke internasjonal, europeisk og nasjonal menneskerettighetslovgivning i relasjon til et vidt spekter av helsetemaer. Målet med å rettighetsfeste er at man da stiller staten ansvarlig for at alle innbyggerne får visse rettigheter. Menneskerettighetsjus kan brukes til å berike de fleste helserelaterte felt og tillegger ofte et nytt, mer internasjonalt og moralsk aspekt til de juridiske analysene av helsespørsmålene.

Forfatterne går inn på de fleste helsefelt som ligger i grensesonen hva gjelder å være det man i dag anerkjenner som en menneskerettighet. De diskuterer flere interessante spørsmål, alt fra om det i det hele tatt er et rasjonale bak å rettighetsfeste goder til hvilke områder dette burde gjelde. Retningsgivende praksis og dommer i spesifikke saker behandles grundig da det er slik praksis og aksept for utfall utformes.

Teksten er delt opp i fire deler. Toebes begynner med å diskutere hvordan de europeiske institusjonene, særlig Europarådet, håndterer helse og menneskerettigheter. Deretter beskriver bidragsyterne de viktigste menneskerettighetene som krysser helsefeltet, og de adresserer ulike temaer som viser sterke bånd mellom helse og menneskerettigheter. Eksempler på dette er pasientrettigheter, rett til reproduktiv helse og gråsonespørsmål som omhandler om et menneske har rett til død på samme måte som det har rett til liv. Til slutt diskuterer de posisjonen til flere ulike sårbare grupper, særlig personer med funksjonshemninger, eldre og barn.

Boken er grundig og godt skrevet og gir god innsikt i rasjonale og praksis i forhold til rettighetsfesting av helsegoder. Målgruppen er i stor grad yrkesgrupper med jusutdanning, da det brukes en del fagterminologi som kan være vanskelig å forstå uten rett fagbakgrunn. I det store og det hele anbefaler jeg boken til mennesker med særlig interesse for feltet og som ønsker å skjønne hvorfor og hvordan vi kan snakke om rett til helse som menneskerettighet, og hva begrepet helse i så tilfelle innebærer.

Publisert: 2. oktober 2012. Tidsskr Nor Legeforen. DOI: 10.4045/tidsskr.12.0835

(C) Tidsskrift for Den norske legeforening 2023. Lastet ned fra tidsskriftet.no 26. april 2023. 